Al-Tanzim : Jurnal Manajemen Pendidikan Islam

E-ISSN: 2549-5720 P-ISSN: 2549-3663

March 2019, Vol. 03 No. 01, p. 102-134

https:// ejournal.unuja.ac.id/index.php/al-tanzim

\title{
IMPLEMENTATION OF FACILITIES AND INFRASTRUCTURE MANAGEMENT IN PUBLIC ELEMENTARY SCHOOLS
}

\author{
Sri Marmoah'1, Dhea Adela1, Muna Fauziah'1 \\ 1 Universitas Sebelas Maret, Surakarta, Indonesia \\ marmuah@staff.uns.ac.id
}

\section{Abstract :}

This study utilized to analyze the implementation of management of school facilities and infrastructure. This type of research is descriptive qualitative conducted in Public Elementary School of 01 Bakipandeyan. Data collection techniques in this study include in-depth interviews (Principals, treasurers, teachers, and school committees) and documentation studies. The validity of the data gathered in this study was technical triangulation (in-depth interviews and documentation) and sources (Principals, teachers, and school committees). Data analysis techniques gather interactive analysis with stages: data reduction, data presentation, and verification. The results showed that the implementation of facilities and infrastructure management in Public Elementary School of 01 Bakipandeyan was carried out through three stages, namely: (1) procurement of facilities (2) utilization and (3) maintenance of facilities and infrastructure. Researchers suggest that schools be better at managing school facilities and infrastructure and looking for specialized workers to manage school facilities and infrastructure.

Key Words: Management, Facilities, Infrastructure 
Al-Tanzim : Jurnal Manajemen Pendidikan Islam

E-ISSN: 2549-5720 P-ISSN: 2549-3663

March 2019, Vol. 03 No. 01, p. 102-134

https:/ / ejournal.unuja.ac.id/ index.php/ al-tanzim

\section{Abstrak :}

Penelitian ini bertujuan untuk menganalisis implementasi manajemen sarana dan prasarana sekolah. Jenis penelitian ini yaitu kualitatif deskriptif yang dilaksanakan di SD Negeri Bakipandeyan 01. Teknik pengumpulan data pada penelitian ini meliputi wawancara mendalam (Kepala Sekolah, bendahara, guru, dan komite sekolah) dan studi dokumentasi. Validitas data yang digunakan dalam penelitian ini adalah triangulasi teknik (wawancara mendalam dan dokumentasi) dan sumber (Kepala Sekolah, guru, dan komite sekolah). Teknik analisis data menggunakan analisis interaktif dengan tahapan: reduksi data, penyajian data, dan verifikasi. Hasil penelitian menunjukkan bahwa implementasi manajamen sarana dan prasarana di $S D$ Negeri Bakipandeyan 01 dilaksanakan melalui tiga tahapan yaitu: (1) pengadaan sarana (2) pendayagunaan dan (3) pemeliharaan sarana dan prasarana. Peneliti menyarankan kepada sekolah agar lebih baik lagi dalam mengatur sarana dan prasarana sekolah dan mencari tenaga kerja khusus untuk mengelola sarana dan prasarana sekolah.

Kata Kunci : Manajemen, Sarana, Prasarana

\section{INTRODUCTION}

School is a large activity in which there are four interrelated components. The four components in question are Administrative Administration Staff, Educational Technical Staff in which there are Principals and Teachers, School Committees as independent bodies that help implement operational education, and students as students who can be placed as consumers with adequate levels of service. The fourth relationship must be synergistic, because 
Al-Tanzim : Jurnal Manajemen Pendidikan Islam

E-ISSN: 2549-5720 P-ISSN: 2549-3663

March 2019, Vol. 03 No. 01, p. 102-134

https:/ / ejournal.unuja.ac.id/ index.php/ al-tanzim

the continuity of school operations is formed from the relationship of "mutualist symbiosis" of the four components because the need for education is so high, of course, must be faced with optimal readiness for the needs of students. Schools equipped with adequate education facilities are good structures for delivering quality education services (Ugwulashi \& Ph, 2017).

The success of educational goals through learning activities in schools is influenced by many factors, one of which is the availability of educational facilities and infrastructure in accordance with the National Education Standards (SNP). The learning process cannot be separated from infrastructure or school facilities (Asiabaka, n.d.; Julius et al., 2015). School facilities consist of several types including academic buildings and non-academic activities, school equipment, sports areas, play areas, fields, parks, roads, rest areas, and canteens. These facilities will affect the quality of education. Students will be better able to receive learning well if they can use physical facilities directly (Ngwaru \& Oluga, 2015). This also has an impact on classroom conditions that are more enjoyable for students.

The urgency of educational facilities and infrastructure is not only related to the level of school conduciveness associated with the learning of their students, but also at the same time an inseparable part of the overall operation of educational institutions. The image of an educational 
Al-Tanzim : Jurnal Manajemen Pendidikan Islam

E-ISSN: 2549-5720 P-ISSN: 2549-3663

March 2019, Vol. 03 No. 01, p. 102-134

https:/ / ejournal.unuja.ac.id/ index.php/ al-tanzim

institution and public trust in an educational institution also related to the facilities and infrastructure it has. The existence of facilities and infrastructure in schools needs to be managed seriously in order to help achieve predetermined educational goals.

Along with changes in the pattern of governance after the implementation of regional autonomy, the current pattern of school management approaches differs from the previous one, which is more nuanced with autonomy. To optimize the provision, utilization, care and control of educational facilities and infrastructure in each type and level of education, it is necessary to adjust the management of facilities and infrastructure. Schools are required to have the independence to regulate and manage school interests according to their own needs and abilities and based on the aspirations and participation of school citizens while still referring to the applicable laws and regulations. Management of educational facilities and infrastructure is the responsibility of the school as stated in Law Number 20 of 2003 concerning Chapter XII National Education System Article 45 paragraph 1 which reads: "Every formal and nonformal education unit provides facilities and infrastructure that meet educational requirements accordingly with the growth and development of students' physical, intellectual, social, emotional and psychological potential" (Government of Republic of Indonesia, 2003). 
Al-Tanzim : Jurnal Manajemen Pendidikan Islam

E-ISSN: 2549-5720 P-ISSN: 2549-3663

March 2019, Vol. 03 No. 01, p. 102-134

https:/ / ejournal.unuja.ac.id/ index.php/ al-tanzim

However, the reality on the ground at this time is not as expected. Some schools do not seem to have adequate facilities and infrastructure. The Central Statistics Agency reported that In 2006, Indonesia was ranked 89th out of 125 countries surveyed by the Global Competitiveness of the World Economic Report Forum (Kusharjanto \& Kim, 2011). At present, around 50 million Indonesians lack access to treated water, 90 million do not have access to electricity and almost 200 million do not have access to telecommunications or connections. What's more, the general scarcity of school infrastructure services in rural areas, especially outside Java and Indonesia. The results of the study also showed that school facilities experienced infrastructure problems because some of these facilities were old, old, and fragile. There are more than half of the total 597 schools in Chicago that were damaged because the building has been built since 1900 (Lunenburg, 2010). This shows that school facilities and infrastructure in various countries still experience the same problems, namely the amount of damage to facilities.

These problems cannot be tolerated, because they will have a greater impact. Facilities and infrastructure are tools that support learning. If the tool is not in accordance with the school's operational standards, then it is possible for students not to receive learning materials properly. Low school facilities are indicated to have an impact on classroom learning activities. Poor facilities can also harm 
Al-Tanzim : Jurnal Manajemen Pendidikan Islam

E-ISSN: 2549-5720 P-ISSN: 2549-3663

March 2019, Vol. 03 No. 01, p. 102-134

https:/ / ejournal.unuja.ac.id/ index.php/ al-tanzim

students when they are studying(Ugwulashi \& Ph, 2017).

Looking at the existing problems, it is necessary to have an in-depth study of the management of facilities and infrastructure in schools. Government Regulation No. 32 of 2013 concerning facilities and infrastructure standards article 1 paragraph 8 explains that the standards for facilities and infrastructure are national education standards relating to minimum criteria about study rooms, sports venues, places of worship, libraries, laboratories, workshops, playgrounds, creating and recreation, as well as other learning resources, which are needed to support the learning process, including the use of information and communication technology (Medium et al., 2019).

In general, the aim of management of educational facilities and infrastructure is to provide services professionally in the field of educational facilities and infrastructure in the context of the implementation of an effective and efficient education process and for the implementation of systematic management of facilities and infrastructure. Management of school facilities in the form of physical teaching and learning environments including several things, such as water, sanitation, classrooms, libraries, and laboratories (South, 2013). School facilities are the priority that schools favor attracting the attention of customers. 
Al-Tanzim : Jurnal Manajemen Pendidikan Islam

E-ISSN: 2549-5720 P-ISSN: 2549-3663

March 2019, Vol. 03 No. 01, p. 102-134

https:/ / ejournal.unuja.ac.id/ index.php/ al-tanzim

Several previous studies have discussed the management of facilities and infrastructure. Research subjects in several articles focused on facility management at the university (Ikediashi \& Aigbavboa, 2019)). In addition, there are several studies that discuss facility management in a company or development (Gartner, 2016; Zavadskas, Kaklauskas, Lepkova, \& Zalatorius, 2001). Management of facilities in the library has also become trending specifically in several studies. Some literature proves that facilities in schools can improve learning, such as the presence of laboratories and drinking water facilities (Saitis \& Saiti, 2004). There are several kinds of literatures that discuss facilities in primary schools but are not focused on activities carried out by schools, such as procurement, maintenance, and use activities.

This study will discuss the components of facilities and infrastructure management in elementary schools. The focus or purpose of this research is to analyze the implementation of management of facilities and infrastructure consisting of procurement systems, utilization systems, maintenance systems, and supporting and inhibiting factors for the implementation of education facilities and infrastructure management at Public Elementary School of 01 Bakipandeyan. This research is an important new thing for discussed so that the results of this study can be taken into consideration by several schools or readers to find out the 
Al-Tanzim : Jurnal Manajemen Pendidikan Islam

E-ISSN: 2549-5720 P-ISSN: 2549-3663

March 2019, Vol. 03 No. 01, p. 102-134

https:/ / ejournal.unuja.ac.id/ index.php/ al-tanzim

implementation of management facilities and infrastructure at the primary school level in detail.

\section{RESEARCH METHOD}

This type of research is descriptive qualitative. Qualitative research is a study that produces descriptive data in writing and orally from the object of observation (Ortiz, 2009). This type of research is a case study. This research was conducted at Public Elementary School of 01 Bakipandeyan who was appointed as the implementer of the school quality improvement program.

Primary data in this study are in-depth interview data to principals, teachers, school treasurers, and committees, and implementation observations are obtained, while secondary data is in the form of documentation of the implementation of school facilities and infrastructure management. Data collection techniques in this study include in-depth interviews, observations, and documentation studies. The indicators of this study are the procurement system, utilization system, maintenance system, and supporting and inhibiting factors for the implementation of education facilities and infrastructure management.

The validity of the data used in this study is triangulation of techniques in the form of in-depth interviews, observations, and documentation for the same 
Al-Tanzim : Jurnal Manajemen Pendidikan Islam

E-ISSN: 2549-5720 P-ISSN: 2549-3663

March 2019, Vol. 03 No. 01, p. 102-134

https:/ / ejournal.unuja.ac.id/ index.php/ al-tanzim

data sources simultaneously, as well as source triangulation to school principals, teachers, school treasurers, and school committees. Data analysis techniques are carried out by stages: data preparation, data analysis, and data interpretation (Ortiz, 2009).

\section{RESULTS AND DISCUSSION}

\section{Procurement of Education Facilities and Infrastructure}

The Public Elementary School of 01 Bakipandeyan is a public school institution that implements school quality improvement programs through the implementation of good facilities and infrastructure management, namely the process of procurement of facilities and infrastructure, improvement of incomplete facilities and infrastructure, and inventory of facilities and infrastructure by the Chairperson of the School Committee. The results of the interview with the Head of the Public Elementary School of 01 Bakipandeyan as follows:

"Regarding the condition or condition in Public Elementary School of 01 Bakipandeyan now in the process of procurement and improvement of facilities and infrastructure, both regarding facilities for learning activities, facilities for places of worship and facilities for school buildings. With the implementation of facilities and infrastructure management that is handled by administrative 
Al-Tanzim : Jurnal Manajemen Pendidikan Islam

E-ISSN: 2549-5720 P-ISSN: 2549-3663

March 2019, Vol. 03 No. 01, p. 102-134

https:/ / ejournal.unuja.ac.id/ index.php/ al-tanzim

personnel who are experts in their fields "(Interview conducted on June 8, 2018)

Schools also make improvements in terms of classroom learning activities, school curricula; the school always strives to provide the best for all school members to improve school quality. In this case, the support and cooperation of the school are very much needed for the implementation of all school programs. This is in accordance with what the Chairperson of the School Committee explained as follows:

"Increasing the process of learning activities, the curriculum used is in accordance with national standards, a means of learning activities, all of which can be realized if carried out properly by the parties involved and the support and cooperation of all school members". (Interview was conducted on June 8, 2018)

Funds for procurement of goods can be obtained through government assistance, special funding for the procurement of goods from the school or from community assistance. In accordance with the information from the headmaster, as follows:

"To finance the purchase of goods usually sought by the principal, usually comes from the assistance of the National Education Agency, for example, the procurement of books, books obtained from the 
Al-Tanzim : Jurnal Manajemen Pendidikan Islam

E-ISSN: 2549-5720 P-ISSN: 2549-3663

March 2019, Vol. 03 No. 01, p. 102-134

https:/ / ejournal.unuja.ac.id/ index.php/ al-tanzim

National Directorate of National Education donations, parents of students, and special funds for the procurement of books from the school". (Interview was conducted on June 8, 2018)

The process of procurement of facilities and infrastructure in Public Elementary School of 01 Bakipandeyan is carried out through a process of analyzing the needs of school facilities and infrastructure by direct observation by the party in charge or through requests by school residents and then classifying goods according to the needs adjusted to the funds owned by the school namely classifying facilities and infrastructure in accordance with the needs of the goods (goods that urgently need and goods that are not so needed), after that the purchase of goods is done through ACC from the principal and Chairperson of the School Committee.

\section{Utilizing Educational Facilities and Infrastructure}

The existence of facilities and infrastructure is very important for the smooth learning process, with complete facilities and infrastructure, the need for media and tools for learning activities will be fulfilled. Teachers are easier to carry out their duties and obligations, students are easier to understand what they are learning, the comfort of classrooms can make students feel at home and not tired of carrying out their activities in school. This is in 
Al-Tanzim : Jurnal Manajemen Pendidikan Islam

E-ISSN: 2549-5720 P-ISSN: 2549-3663

March 2019, Vol. 03 No. 01, p. 102-134

bttps: / / journal.unuja.ac.id/ index.php/ al-tanzim

line with what was conveyed by the Principal as follows: "With complete facilities the learning process runs smoothly, learning activities become more interesting and children do not get bored in attending lessons because of the use of various kinds of media learning activities, the learning process becomes smooth and enjoyable, all school residents, especially teachers can follow innovations technology for learning activities, children are easier to carry out learning activities and access knowledge through internet facilities by procuring hot spots in schools equal to other schools that are good in their management" (Interview was conducted on June 8, 2018).

While the Chairperson of the School Committee revealed:

"With the complete educational facilities and infrastructure, the teacher's needs for facilities and infrastructure in learning activities can be fulfilled, so that a teacher can carry out his duties well, the teacher is easier to provide material with a variety of strategies for learning activities, and students are more easy to understand the material with various methods used by the teacher because each student is different in terms of capturing material so that the learning process can run smoothly so that the 
Al-Tanzim : Jurnal Manajemen Pendidikan Islam

E-ISSN: 2549-5720 P-ISSN: 2549-3663

March 2019, Vol. 03 No. 01, p. 102-134

https:// ejournal.unuja.ac.id/ index.php/al-tanzim

quality of learning activities increases because it is supported by various facilities and infrastructure that have been provided by the school". (Interview conducted on June 8, 2018)

The use of facilities and infrastructure in learning activities is very varied, all facilities and infrastructure can be used as tools or media for learning activities depending on the strategies or methods used by the teacher in teaching, besides the subject matter factors also determine the use of facilities and infrastructure. In this case, the selection in the use of facilities and infrastructure greatly determines the success of the learning activities process; here the teacher has an important role in it. It takes the creativity of the teacher in learning activities so that the desired learning activities can be realized well. Interviews conducted by researchers with the teacher's father in Public Elementary School of 01 Bakipandeyan as follows:

"In using facilities and infrastructure depending on the needs adjusted to the material being studied, for example material about the history of Islamic civilization, students use library facilities to be used as a source of knowledge through the books in it, while for the practice of praying pilgrims use the means the mosque owned by the school". (Interview was conducted on June 8, 2018) 
Al-Tanzim : Jurnal Manajemen Pendidikan Islam

E-ISSN: 2549-5720 P-ISSN: 2549-3663

March 2019, Vol. 03 No. 01, p. 102-134

https:/ / ejournal.unuja.ac.id/ index.php/ al-tanzim

With the use of facilities and infrastructure, it is expected that there will be benefits for improving the quality of learning activities carried out in schools, both in terms of the understanding of students, as well as the achievement results obtained by students.

Based on and direct observations made in Public Elementary School of 01 Bakipandeyan the facilities and infrastructure owned are quite good, from several observations of the infrastructure owned already complete and good at the learning activities facilities already using audio-visual equipment, laptops, OHPs, LCDs and now schools have planned learning activities that lead to IT-based learning activities, in addition to mosque facilities, libraries, bathrooms, classrooms, UKS rooms, places of ablution are very good and good and meet the standards and in a ready to use condition so that all school residents can use the facility if needed.

After the facilities and infrastructure needed have been owned by the school then in terms of utilization/use of facilities and infrastructure must be carried out effectively and efficiently according to its function, so that the goods that have been purchased can be useful as needed. Utilization of goods related to the process of using and borrowing goods carried out by school residents. The process of entry and exit of goods is recorded in a special book in and out of goods which is 
Al-Tanzim : Jurnal Manajemen Pendidikan Islam

E-ISSN: 2549-5720 P-ISSN: 2549-3663

March 2019, Vol. 03 No. 01, p. 102-134

https:/ / ejournal.unuja.ac.id/ index.php/ al-tanzim

the responsibility of the officer in the respective fields of infrastructure. As stated by the Chairman of the School Committee, as follows:

"Borrowing or use of goods must fulfill the procedure, namely contacting the officer who is specifically responsible for the goods needed, then by the officer noted in the specific book for borrowing goods, the entry and exit of goods is the responsibility of the personnel so that the utilization process of goods can be carried out to the maximum with needs". (Interview was conducted on June 8, 2018)

The facilities and infrastructure owned by the school are not only kept well so that they remain intact and not damaged, but rather to be used to support the effective learning process. Thus, in terms of utilization of facilities and infrastructure must be used properly and in accordance with these needs so that the benefits from the use of these goods can be obtained to the maximum. Good utilization, for example in the tools of learning activities that are used by teachers in learning, the teacher can take advantage of the use of learning media to improve students' understanding of the material with a variety of methods and more interesting and meaningful learning strategies. 
Al-Tanzim : Jurnal Manajemen Pendidikan Islam

E-ISSN: 2549-5720 P-ISSN: 2549-3663

March 2019, Vol. 03 No. 01, p. 102-134

https:/ / ejournal.unuja.ac.id/ index.php/ al-tanzim

\section{Maintenance of Educational Facilities and Infrastructure}

The process of maintaining goods in Public Elementary School of 01 Bakipandeyan is left to the parties responsible for each facility. This process involves the distribution, use and borrowing of facilities and infrastructure by school residents who need it, the arrangement of facilities and infrastructure in accordance with the place, and maintenance of facilities and infrastructure so that they can be used successfully. This is in accordance with what the Chairperson of the School Committee said, as follows:

"Maintenance of goods concerns the process of distributing goods to the parties in charge of each field of facilities and infrastructure such as computers to the IT department, so the process of maintaining goods is left to those responsible in their fields, the Chairperson of the School Committee only manages, maintenance facilities and infrastructure is carried out every day and periodically by each field of facilities and infrastructure, which includes supervision, checking the entry and exit of goods, prevention of damage, cleaning of facilities and infrastructure which are then reported to the Chairperson of the School Committee. "(Interview conducted on 8 June 2018) 
Al-Tanzim : Jurnal Manajemen Pendidikan Islam

E-ISSN: 2549-5720 P-ISSN: 2549-3663

March 2019, Vol. 03 No. 01, p. 102-134

https:/ / ejournal.unija.ac.id/index.php/al-tanzim

4. Supporting and Inhibiting Factors in Managing Standard Facilities and Infrastructure

The internal factors that support the management of school facilities and infrastructure standards in Public Elementary School of 01 Bakipandeyan in accordance with what was conveyed by the Principal are as follows:

"The internal factors that support the implementation of management of school facilities and infrastructure standards in Public Elementary School of 01 Bakipandeyan are the experience of teachers and staff. All teachers and staff (TU) already have sufficient experience because in this school the teacher and his staff have carried out assignments for more than 5 years. So the teacher and staff understand well the character and conditions that exist in this school. "(Interview conducted on June 8, 2018)

While the external factors as supporters in managing the standards of facilities and infrastructure delivered by the Principal are:

"In managing school facilities and infrastructure, the external factors that support them are the existence of good participation from the community through the school committee so that we are able to manage and procure facilities and infrastructure that are not yet available. In addition, the school committee 
Al-Tanzim : Jurnal Manajemen Pendidikan Islam

E-ISSN: 2549-5720 P-ISSN: 2549-3663

March 2019, Vol. 03 No. 01, p. 102-134

https:/ / ejournal.unuja.ac.id/ index.php/ al-tanzim

together with the community has been able to raise funds for the development and renovation of school facilities and infrastructure which really need to be addressed immediately" (Interview was conducted on June 8,2018 )

Meanwhile according to the Chairperson of the School Committee that the factors supporting the management of school facilities and infrastructure standards were the participation of the government through the assistance of the Special Allocation Fund, BOS Funds and assistance from several parties through the Education Agency. Constraints in managing school facilities and infrastructure standards in the opinion of the principal are:

"There is limited space or space for shelves to store or store some facilities, especially learning facilities in the form of media and teaching aids. Besides that there is a shortage of workers who specifically care for the facilities and infrastructure owned by the school as well as the budget provided by the government is still very limited so we have to adjust and save the budget for maintenance of facilities and infrastructure in schools" (Interview was conducted on June 8,2018 ) 
Al-Tanzim : Jurnal Manajemen Pendidikan Islam

E-ISSN: 2549-5720 P-ISSN: 2549-3663

March 2019, Vol. 03 No. 01, p. 102-134

https:/ / ejournal.unija.ac.id/index.php/al-tanzim

The interview data is supported by school documentation. School documentation activities show that the implementation of infrastructure management has been implemented properly. The following are the results of a study of documentation of data on educational facilities and infrastructure in Public Elementary School of 01 Bakipandeyan.

Table 2.2

Data on Education Facilities and Infrastructure in Public Elementary School of 01 Bakipandeyan

\begin{tabular}{clcc}
\hline No & \multicolumn{1}{c}{ Room } & Amount & $\begin{array}{c}\text { Type of } \\
\text { Information }\end{array}$ \\
\hline 1 & Principal's room & 1 & Good \\
2 & Teacher's room & 1 & Good \\
3 & Class & 10 & Good \\
4 & Library & 1 & Good \\
5 & Places of worship & 1 & Good \\
6 & Teacher's Toilet & 1 & Good \\
7 & Student's Toilet & 6 & Good \\
8 & Sport Field & 1 & Good \\
9 & Science LAB & - & - \\
10 & UKS Room & 1 & Good \\
\hline
\end{tabular}

The data in the table above shows that the facilities and infrastructure as a whole are in good condition. School has several rooms with good condition. The several rooms namely: one of principal's room with good 
Al-Tanzim : Jurnal Manajemen Pendidikan Islam

E-ISSN: 2549-5720 P-ISSN: 2549-3663

March 2019, Vol. 03 No. 01, p. 102-134

https:/ / ejournal.unuja.ac.id/ index.php/ al-tanzim

condition, one of teacher's room with good condition, ten classes with good condition, one of library with good condition, one of places of worship with good condition, one of teacher's toilet with good condition, six of student's toilet with good condition, one of sport field with good condition, and one of UKS's room with good condition.

The implementation of facilities and infrastructure management carried out in Public Elementary School of 01 Bakipandeyan covers several things, namely procurement, use, maintenance, and the factors that influence it. Basically, the implementation of management of facilities and infrastructure must be carried out through an operation, maintenance, development, and adaptation or prevention approach to the implementation of the inhibiting factors (Odediran et al., 2015). The description of the implementation of facilities and infrastructure management in Public Elementary School of 01 Bakipandeyan as follows:

The procurement of facilities and infrastructure in Public Elementary School of 01 Bakipandeyan is done by purchasing the necessary facilities and infrastructure, getting donations from the education office and parents of students and the community. Funds for procurement of goods in Bakipandeyan Public Elementary School 01 were obtained from funds owned by the school, donations from the government, and donations from parents of students. 
Al-Tanzim : Jurnal Manajemen Pendidikan Islam

E-ISSN: 2549-5720 P-ISSN: 2549-3663

March 2019, Vol. 03 No. 01, p. 102-134

https:/ / ejournal.unuja.ac.id/ index.php/ al-tanzim

Procurement of goods must be through the approval of the principal and school board through the Deputy Principal of infrastructure facilities by proposing the purchase of goods to complete school facilities and infrastructure.

Procurement of goods at Public Elementary School of 01 Bakipandeyan regularly every month, this is basically done to meet the needs of facilities and infrastructure in the school. Facilities and infrastructure are provided to support the process of learning activities. The procurement of school facilities and infrastructure is carried out in various ways according to the types of facilities and infrastructure needed (Kusharjanto \& Kim, 2011). An inventory of good facilities and infrastructure can be known what facilities and infrastructure that have not been owned and needed by the school community so that the demand for goods can be done optimally.

To provide educational facilities and infrastructure can be done in various ways. For example, for land acquisition can be done by buying, receiving grants, accepting usage rights, exchanging and so on. Procurement of buildings/buildings can be done by building new, buying, receiving grants, or exchanging buildings. To procure school equipment or furniture can be done by buying. The furniture to be purchased can take the form of a finished one or one that has not yet been made. Procurement of this equipment can also be done by making it yourself or 
Al-Tanzim : Jurnal Manajemen Pendidikan Islam

E-ISSN: 2549-5720 P-ISSN: 2549-3663

March 2019, Vol. 03 No. 01, p. 102-134

https:/ / ejournal.unuja.ac.id/ index.php/ al-tanzim

receiving assistance from government agencies from outside the Ministry of National Education, private bodies, communities, individuals and so on. Procurement of equipment is also adjusted to the policies of the school so that the achievement of results can be clearly measured (Gartner, 2016).

In the procurement of the above facilities, in addition to the quality and quantity aspects that need to be considered, procedures or legal basis are also considered, so that existing facilities do not cause problems in the future. For example, in purchasing land, it is necessary to clear the land documents to be purchased, as well as the purchase certificate, as well as receiving grants from other parties so that there is a legal basis, preferably in the Notary Act of the local land deed maker. Regarding the purchase of the right to use, such as land should be accompanied by a handover document from the party that gives the right to use.

In each school, there should be special officers who carry out tasks related to equipment. Its activities include receiving, storing and removing goods from goods storage/warehouse. In storing goods, it is also necessary to pay attention to the storage area of the goods. Storage is done so that the facilities and infrastructure in the school are not quickly damaged before the usage period arrives (Marmoah \& Denmar, 2017). Warehouses should be placed in easily accessible locations, supporting facilities, such as 
Al-Tanzim : Jurnal Manajemen Pendidikan Islam

E-ISSN: 2549-5720 P-ISSN: 2549-3663

March 2019, Vol. 03 No. 01, p. 102-134

https:/ / ejournal.unuja.ac.id/ index.php/ al-tanzim

electricity, water, etc. (Figueroa, Lim, \& Lee, 2016). The warehouse must be in good condition. To ensure the implementation of storage of goods or educational facilities, the following matters must be considered: (1) applicable warehousing conditions; (2) the nature of the goods stored; (3) storage period; (4) tools or other facilities needed for storage; (5) funds or costs for maintenance; and (6) clear storage work procedures and adapted to the nature of the items stored.

Utilization of facilities and infrastructure in Public Elementary School of 01 Bakipandeyan conducted through learning activities is very varied using tools or media learning activities. Teachers are easier to teach students so that students feel at home and not tired of carrying out their activities at school. Facilities provided such as hotspots, audio-visual equipment, laptops, OHPs, LCDs, and IT-based learning. Sources of IT services are important because schools need good access to develop learning through tutorials in cyberspace (Aziz, Nawawi, \& Ariff, 2016). Other facilities such as prayer rooms, libraries, bathrooms, classrooms, UKS rooms, ablution rooms are also very good, meet the standards, and are ready to use so that school residents can use these facilities if needed.

Utilization/use of facilities and infrastructure activities are also related to the process of using and borrowing goods carried out by school residents by doing in special books in 
Al-Tanzim : Jurnal Manajemen Pendidikan Islam

E-ISSN: 2549-5720 P-ISSN: 2549-3663

March 2019, Vol. 03 No. 01, p. 102-134

https:/ / ejournal.unuja.ac.id/ index.php/ al-tanzim

and out of goods. This was answered by officers in the respective fields of infrastructure. All school facilities and infrastructure are inventoried, such as number, type of goods, quality, year of manufacture, brand, size, price and so on. Especially for educational facilities and infrastructure originating from the government (state-owned), an accurate inventory is carried out, using predetermined formats or recording their inventory in the Master Book of Inventory Items and Books in the Inventory Group.

Facilities and infrastructure are supporting the active learning process. These items will not remain in condition, but over time it will lead to damage, destruction and even extinction. However, so that the facilities and infrastructure are not quickly damaged or destroyed, a good maintenance effort is needed from the wearer. Maintenance or maintenance is an ongoing activity to make sure that the existing educational facilities and infrastructure are in good condition and ready to be used.

Maintenance is an activity by procuring costs that are included in the entire school budget and intended for the continuity of building, equipment, and furniture, including the provision of costs for the benefit of repairs and renovations, as well as replacement. Providing school facilities is very important, but maintaining these facilities is an important condition for improving the good academic environment (Ugwulashi \& Ph, 2017). Provision of school 
Al-Tanzim : Jurnal Manajemen Pendidikan Islam

E-ISSN: 2549-5720 P-ISSN: 2549-3663

March 2019, Vol. 03 No. 01, p. 102-134

https:/ / ejournal.unuja.ac.id/ index.php/ al-tanzim

facilities is very important and the maintenance of facilities is a condition that is also important for improving the good academic environment. The learning process will be more effective and quality if supported by adequate facilities and infrastructure, one of which is in literacy activities (Ngwaru \& Oluga, 2015). The learning process is a series of activities carried out by teachers and students by utilizing the facilities and infrastructure available to obtain optimal learning outcomes (Vivian, Nkong, George, \& Mohamadou, 2016).

Maintenance of facilities and infrastructure in Public Elementary School of 01 Bakipandeyan is carried out by each officer who is specialized in the field of facilities and infrastructure. The activities range from checking goods, supervising goods, repairing items that are lightly damaged and heavily damaged and laying out facilities and infrastructure, while daily maintenance of facilities and infrastructure is carried out, namely checking and cleaning of facilities and infrastructure so that they are always ready to use when - school time needs.

Facilities and infrastructure have an important role in the learning process at school. Physical assets and facilities are unity in an educational institution and learning environment (Musa \& Ahmad@Baharum, 2012). Management of educational facilities and infrastructure which includes educational media which has an important 
Al-Tanzim : Jurnal Manajemen Pendidikan Islam

E-ISSN: 2549-5720 P-ISSN: 2549-3663

March 2019, Vol. 03 No. 01, p. 102-134

https:/ / ejournal.unuja.ac.id/ index.php/ al-tanzim

role and is needed for the smooth learning process. With the completeness of learning facilities and infrastructure in schools, the quality of learning can be increased as well, one of which is an increase in students' understanding of the material so that student learning achievements become good.

The implementation of facilities and infrastructure management in Public Elementary School of 01 Bakipandeyan does not always run smoothly. There are two factors that influence its implementation, namely internal and external factors. Internal factors that support the management of school facilities and infrastructure standards in the form of teacher and staff experience. Teachers who have carried out their duties for more than five years better understand the character and condition of the school. Its external factor is in the form of community support and their role through the school committee so that the school is able to manage the procurement of inadequate facilities and infrastructure. Funds for development and renovation are still carried out independently or student guardian fees. In addition to these two factors, the role of the government through the Special Allocation Fund, the School Operational Assistance Fund, and assistance from the Education Office are very helpful in implementing the school. The process of building maintenance requires a budget that is sufficiently large to investigate and overcome this so that a periodic plan 
Al-Tanzim : Jurnal Manajemen Pendidikan Islam

E-ISSN: 2549-5720 P-ISSN: 2549-3663

March 2019, Vol. 03 No. 01, p. 102-134

https:/ / ejournal.unuja.ac.id/ index.php/ al-tanzim

is needed that is prioritized on a number of materials and the frequency of maintenance in a year (Hamzah \& Kobayashi, 2013).

The constraints in the management of school facilities and infrastructure are the limited space and space to deviate goods, the lack of workers who specifically manage the facilities, and the absence of a budget to maintain school facilities and infrastructure. Infrastructure management is also influenced by the technical implementation, finance, environment, and human resources (Abuzayan, Whyte, \& Bell, 2014). The intended human resources are those who must take care of the infrastructure. Labor is needed so that maintenance can be optimally carried out.

Based on the description above, it can be concluded that the implementation of facilities and infrastructure management in Public Elementary School of 01 Bakipandeyan has been well implemented, although in its implementation there are still obstacles that hamper. The implementation process is in accordance with the rules or standards determined by the government. The stages carried out in the form of procurement, utilization, and maintenance of school facilities and infrastructure that have been carried out in accordance with existing procedures. The procurement of facilities and infrastructure in Public Elementary School of 01 Bakipandeyan is done by purchasing the necessary facilities and infrastructure, 
Al-Tanzim : Jurnal Manajemen Pendidikan Islam

E-ISSN: 2549-5720 P-ISSN: 2549-3663

March 2019, Vol. 03 No. 01, p. 102-134

https:/ / ejournal.unuja.ac.id/ index.php/ al-tanzim

getting donations from the education office and parents of students and the community. Utilization through inverted goods activities in and out so that it is well recorded and also the learning process that is supported by innovative media, internet facilities, and IT-based learning. Maintenance of facilities and infrastructure in Public Elementary School of 01 Bakipandeyan is carried out by each officer who is specialized in the field of facilities and infrastructure. In the implementation of the three stages, it is influenced by several things related to internal elements (educators and education) and external elements (committee, student guardians, and government assistance). Constraints mean in the implementation of management facilities and infrastructure in the form of a lack of workers who take care of the goods and lack of budget allocation to maintain school facilities and infrastructure.

\section{CONCLUSIONS}

Facilities and infrastructure are important things that influence the quality of education in schools. Starting from the results and discussion above, it can be concluded that the implementation of facilities and infrastructure management in Public Elementary School of 01 Bakipandeyan has been implemented well through three stages, namely: (1) procurement of facilities by purchasing the necessary facilities and infrastructure, obtaining 
Al-Tanzim : Jurnal Manajemen Pendidikan Islam

E-ISSN: 2549-5720 P-ISSN: 2549-3663

March 2019, Vol. 03 No. 01, p. 102-134

https:// ejournal.unija.ac.id/ index.php/al-tanzim

donations from the National Education Agency and parents of students and the community; (2) utilization through in vertical activities of goods that come out and enter so that they are well recorded and also the learning process that is supported by innovative media, internet facilities, and ITbased learning; and (3) the maintenance of facilities and infrastructure in Public Elementary School of 01 Bakipandeyan is carried out by each officer who is specialized in the field of facilities and infrastructure. The researcher suggested that the school be better in managing school facilities and infrastructure. Constraints faced in the implementation need to be followed up by looking for special workers to manage school facilities and infrastructure. 
Al-Tanzim : Jurnal Manajemen Pendidikan Islam

E-ISSN: 2549-5720 P-ISSN: 2549-3663

March 2019, Vol. 03 No. 01, p. 102-134

https:/ / ejournal.unuja.ac.id/ index.php/ al-tanzim

\section{REFERENCES}

Abuzayan, K. M. A., Whyte, A., \& Bell, J. (2014). Assetmanagement framework(s) for infrastructure facilities in adverse (post-conflict/disaster-zone/high-alert) conditions. Procedia Economics and Finance, 18(September), 304-311. https://doi.org/10.1016/s2212-5671(14)00944-7

Asiabaka, I. P. (n.d.). FACILITIES MANAGEMENT IN SCHOOLS. 10-21.

Aziz, N. D., Nawawi, A. H., \& Ariff, N. R. M. (2016). ICT Evolution in Facilities Management (FM): Building Information Modelling (BIM) as the Latest Technology. Procedia - Social and Behavioral Sciences, 234, 363-371. https://doi.org/10.1016/j.sbspro.2016.10.253

Figueroa, L. L., Lim, S., \& Lee, J. (2016). Investigating the relationship between school facilities and academic achievements through geographically weighted regression. Annals of GIS, 22(4), 273-285. https:/ / doi.org/10.1080/19475683.2016.1231717

Gartner, C. (2016). The Science and Politics of Infrastructure Research: Asserting Power, Place, and Agency in Infrastructure Knowledge. Journal of Human Development and Capabilities, 17(3), 377-396. https://doi.org/10.1080/19452829.2016.1198309 
Al-Tanzim : Jurnal Manajemen Pendidikan Islam

E-ISSN: 2549-5720 P-ISSN: 2549-3663

March 2019, Vol. 03 No. 01, p. 102-134

https:// ejournal.unuja.ac.id/index.php/al-tanzim

Government of Republic of Indonesia. (2003). Act of the Republic of Indonesia on National Education System 1. System, (20), 1-58. https://doi.org/10.1111/jonm.12155 Hamzah, S., \& Kobayashi, K. (2013). Utilizing Mid-long Term Maintenance Management Policy for Sustainable Maintenance of Infrastructure Facilities. Procedia Environmental Sciences, 17, 478-484. https://doi.org/10.1016/j.proenv.2013.02.062

Ikediashi, D., \& Aigbavboa, C. (2019). Outsourcing as a strategy for facilities management provision in Nigerian universities. International Journal of

Construction Management, 19(4), 281-290. https://doi.org/10.1080/15623599.2018.1435235

Julius, S., Job, O., Gbadegesin, T., Olubola, M., Julius, S., Job, O., ... Olubola, M. (2015). Article information:

Kusharjanto, H., \& Kim, D. (2011). Infrastructure and human development: The case of Java, Indonesia. Journal of the Asia Pacific Economy, 16(1), 111-124. https://doi.org/10.1080/13547860.2011.539407

Lunenburg, F. C. (2010). School Facilities Management. 27(4), 1-7.

Marmoah, S., \& Denmar, D. (2017). The Analysis Of Classroom Management In Teaching English. 22(1), 72-78. https://doi.org/10.9790/0837-2201037278 
Al-Tanzim : Jurnal Manajemen Pendidikan Islam

E-ISSN: 2549-5720 P-ISSN: 2549-3663

March 2019, Vol. 03 No. 01, p. 102-134 https:// ejournal.unuja.ac.id/index.php/al-tanzim

Medium, N., Development, T., Number, P. R., Entities, B., Provision, I., Regulation, P., ... Number, P. R. (2019). No Title. (67).

Musa, M. F., \& Ahmad@Baharum, Z. (2012). Higher Education Physical Assets and Facilities. Procedia Social and Behavioral Sciences, 50(July), 472-478. https://doi.org/10.1016/j.sbspro.2012.08.051

Ngwaru, J. M., \& Oluga, M. (2015). Educational infrastructure and resources for sustainable access to schooling and outcomes: The case of early literacy development in Southern Tanzania. Africa Education Review, 12(1), 88-108. https://doi.org/10.1080/18146627.2015.1036570

Odediran, S. J., Gbadegesin, J. T., Babalola, M. O., Ikediashi, D., Ekanem, A. M., Isa, M. F. M., \& Usmen, M. (2015). Article information:

Ortiz, D. (2009). Research Design: Qualitative, Quantitative, and Mixed Methods Approaches [Book Review]. Qualitative Research Journal, 6(2), [205]-207. https://doi.org/10.3316/qrj0602205

Saitis, C., \& Saiti, A. (2004). School libraries in Greece: A comparative study of public primary schools in rural and urban areas. Library and Information Science Research, 26(2), 201-220. https://doi.org/10.1016/j.lisr.2003.12.004 
Al-Tanzim : Jurnal Manajemen Pendidikan Islam

E-ISSN: 2549-5720 P-ISSN: 2549-3663

March 2019, Vol. 03 No. 01, p. 102-134

bttps:/ / ejournal.unuja.ac.id/ index.php/ al-tanzim

South, V. (2013). S CHOOLS P OLICY IN R URAL S OUTH A FRICAN S CHOOLS: L ESSONS FROM THE. 8(5), 113.

Ugwulashi, C. S., \& Ph, D. (2017). Educational Facilities: Appropriate Strategy for School Safety Management in Rivers State , Nigeria. 6(2), 11-19. https://doi.org/10.6007/IJARPED/v6-i2/2317

Vivian, M., Nkong, M., George, F. E., \& Mohamadou, G. (2016). The Effects of School Facilities on Educational Quality. The Case of Public Primary Schools in KupeMuanenguba Division, South-West Region of Cameroon. (6), 37-39.

Zavadskas, E. K., Kaklauskas, A., Lepkova, N., \& Zalatorius, J. (2001). Facilities management multiple criteria analysis. Statyba, 7(6), 481-489. https://doi.org/10.1080/13921525.2001.10531776 